\section{Screening for Covert Bacteriuria}

SIR,-MacConkey's medium was intentionally made inhibitory so as to simplify work with Gram-negative bacteria of faecal origin Some Gram-positive organisms will not grow on it at all, and the speed and profusion of growth of those that will are markedly altered by minor variations in its formulation. For this reason Mr. R. Hole's doubts (19 July, p. 160) about the use of CLED medium for urinary bacteriology, and his inference that MacConkey's medium is superior to it for this purpose, should not be accepted uncritically, because the exclusive use of MacConkey's medium must perpetuate a narrow view of the possible range of urinary pathogens.

The significance of Gram-positive organisms other than Streptococcus faecalis as causes of urinary tract infection has attracted rather low-key attention for many years, but the pathogenic role of certain strains of coagulase-negative staphylococci seems now as firmly based as is that of Escherichia coli. There is thus a good reason for suggesting that a non-selective medium like CLED should always be used in urinary bacteriology in preference to an inhibitory medium like MacConkey's. To take the opposite view is to extinguish not only a number of potential pathogens, but also the possibility of argument about them.-I am, etc.,

Public Health Laboratory

Plymouth, Devon

P. D. MEERS

\section{Antibiotic Policy}

SIR,-Mr. O. J. A. Gilmore and Dr. P. J. Sanderson (19 July, p. 161) have attacked the use of topical antibiotic prophylaxis of surgical wound sepsis without producing a shred of evidence for their statements that this policy encourages skin sensitivity and bacterial resistance. They extol the virtue of a topical application of povidone-iodine, but we have shown ${ }^{1}$ that in potentially contaminated operations the rate of primary wound sepsis was almost three times as great after povidone-iodine prophylaxis $(32 \%)$ as it was after intra-incisional instillation of cephaloridine $1 \mathrm{~g}$ dissolved in $2 \mathrm{ml}$ of water $(11 \%)$. The emergence of bacterial resistance associated with topical chemoprophylaxis has been recorded only after repeated applications of antibiotics for the control of secondary sepsis in burns. ${ }^{2}$

We have used cephaloridine successfully for the prophylaxis of wound sepsis in a series of controlled clinical trials in more than 1200 patients over the past four years. Scrutiny of the bacteriological records of organisms from all hospital patients in 1971 and 1974 showed a resistance rate to cephaloridine of $20.4 \%$ and $20.5 \%$ respectively. In no single species was there evidence of emergence of resistant strains. No patient in the entire series developed skin sensitivity or any other signs of toxicity. Nevertheless, though we are satisfied that at present our use of topical cephaloridine is not altering the hospital flora in any way, we thall continue our search for an agent which is both as effective as cephaloridine and not in use as a systemic therapeutic agent.-We are, etc.,

A. V. Pollock MARY EVANS Scarborough Hospital,
Yorkshire
1 Pollock, A. V., and Evans, Mary, British fournal of Surgery, i975, 62, 292.

Lowbury, E. J. L., and Ayliffe, G. A. J., Drug Resistance in Antimicrobial Therapy. Spring field, Thomas, 1974.

\section{Colour Disturbance as a Symptom}

SIR,-I write in reply to Dr. M. J. Pleydell's question (19 July, p. 159) about the repercussions of colour disturbance in doctors and those in other occupations. I first learn of my red-green colour blindness as an undergraduate when I was shown the Isihara test. I remember being incredulous and a little resentful, and remonstrated with none less than Sir Charles Sherrington. I recall great difficulties with histology, and eventually had to bluff my way through using means other than colour with which to detect small nucleoli, etc. After the war I lived perhaps more exuberantly than some, and well remember my fellow registrars complaining (as now) how their small income was insufficient even for very modes social undertakings. I remember telling my wife I thought they were an over-cautious lot, saying "I get a statement from the bank every month and each time it seems bigger." She asked to see the statement, and I reversed my attitude abruptly when she pointed out it was in red.

The most serious implication in medicine is that of the recognition of cyanosis. I have become more aware of this shortcoming (though I was slow to realize it) and it is one reason why as a psychiatrist $I$ would be most hesitant to give E.C.T. without an anaesthetist. One develops compensatory mechanisms but not to the point of reliability. Since one male in 12 is so affected it is a matter for wonderment that for innumerable years red and green have been the acknowledged signs for danger and safety. I am told that even a person with normal vision has difficulty seeing red traffic lights when the sun is shining on them. This is much more true of the colour blind. Why could such lights not be bisected, half red and half yellow and half green and half blue, or even have diagonal lines on red lights and stippling on green ones? It seems such a simple and inexpensive solution to such a common and important problem.-I am, etc.,

Queen Elizabeth Hospital

R. W. TIBBETTS Birmingham

SIR,-In reply to Dr. M. J. Pleydell (19 July, p. 159) may I relate my own experience of defective red/green colour vision? The abnormality was diagnosed by a colleague using Ishihara test cards when we were undergraduates and later confirmed at my army medical examination. The defect runs in my mother's side of the family in the usual sex-linked manner. The only way it has affected me personally is that $I$ have always found great difficulty in seeing Ziehl-Neelsenstained tubercle bacilli. The red devils always escape me. This, however, has never affected my profession as a gynaecologist and only meant that I skipped practical clinical bacteriology as a medical student and retired to the golf course. $-\mathrm{I}$ am, etc.,

ALAN M. SMITH

\section{Vagotomy for Duodenal Ulcer}

SIR,-We would like to comment on the controversy which has arisen in your columns between Drs. P. Madsen and $O$. Kronborg (21 June, p. 688) and Mr. D. Johnston and Professor J. C. Goligher (12 July, p. 101). The heart of this controversy appears to be the reliability of Hollander's criteria for interpreting the postvagotomy insulin test. These criteria are of some help in forecasting recurrent ulceration when they are applied to groups of subjects but of no value in the individual patient, a point which Hollander himself emphasized. ${ }^{1}$

Our recent publications ${ }^{34}$ throw some light on this matter. The lack of reliability of the Hollander criteria is largely due to the variability of basal gastric secretion ${ }^{5}$ and also, to some extent, to errors produced by pyloric losses and duodenogastric reflux. Even without correcting for the latter factors the reliability of the insulin test is greatly improved by considering the acid output after insulin without reference to the basal. Male patients with a peak acid output (P.A.O.I) (uncorrected) in excess of $8 \mathrm{mmol} / \mathrm{h}$ have much greater than $50 \%$ liability to recurrent ulceration, while those producing less than $8 \mathrm{mmol} / \mathrm{h}$ have virtually no risk of recurrence. For example, this criterion applied to Kronborg and Madsen's data ${ }^{6}$ gives a "positive" result in all but two of their recurrent ulcer cases. One of these was a woman and we do not yet have sufficient data to establish the critical P.A.O.I in women, while the other was a man with a P.A.O.I of $7.6 \mathrm{mmol} / \mathrm{h}$ who may be an example of the need for correction for reflux and pyloric losses. ${ }^{3} \mathrm{~A}$ further advantage of our method of interpretation is that it seems to be independent of the length of time after vagotomy when the test is performed. ${ }^{4}$

It would be interesting to know what picture would emerge if both these groups of investigators recalculated their results along the lines we have described.-We are, etc.,

Middlesex Hospital

R. G. FABER J. V. PARKIN M. HOBSLEY

London W.1

1 Hollander, F., Gastroenterology, 1948, 11, 419 2 Weinstein, V. A., et al., Gastroenterology, 1950 , $14,214$.

3 Faber, R. G., et al., Gut, 1975, 16, 337.

4 Faber, R. G., et al., Gut, 1975, 16, 343.

6 Baron, J. H., Gut, 1963, 4, 136.

Alternative to Slow-release Potassium Tablets

SIR,-It has puzzled me for years why physicians prescribe slow-release potassium tablets, with the known complication of intestinal ulceration. If oral potassium supplements are required with diuretic therapy the more palatable and bettertolerated equivalent is fruit juice. The sodium content is very low and average potassium contents per $100 \mathrm{~g}$ are as follows: apple juice $2.6 \mathrm{mmol}(100 \mathrm{mg})$, grape juice $3.1 \mathrm{mmol}(120 \mathrm{mg})$, grapefruit juice 3.8 mmol (150 mg), orange juice $4.9 \mathrm{mmol}$ (190 $\mathrm{mg}$ ), pineapple juice $3.6 \mathrm{mmol}(140 \mathrm{mg})$, raspberry juice $3.6 \mathrm{mmol}(141 \mathrm{mg}){ }^{1}$

A glass of fresh orange juice twice a day provides $25 \mathrm{mmol}$ potassium and should not disturb fluid balance significantly. The juice can be ingested after meals and smaller 
amounts given more often if desired to even it was formerly regarded as benign-hence out absorption through the day.-I am, etc.,

Hammersmith Hospital,

D. F. HAWKINS

London W.12

1 Documents Geigy Scientific Tables (1970), ed. K. Diem and C. Lentner, 7th edn., p. 499. Basle, Geigy.

\section{Genital Medicine}

SIR,-Dr. R. N. T. Thin (5 July, p. 43) calls our specialty by yet another name, Genital Medicine, a title which some might consider too bald. However, it is better than "Genitourinary Medicine," which I criticized (24 May, p. 446), because that implies poaching on other people's fields with the possible danger of neglect of the venereal or sexually transmitted diseases (S.T.D.) in favour of more academically interesting ones. However, both these titles are, to my mind, unsatisfactory as they refer to a circumscribed area of the body, whereas S.T.D. often involves the whole person-for example, syphilis or Reiter's syndrome. Lines of demarcation as to who does what may sometimes be necessary but not in this case. The problem of finding a suitable title for the departments where S.T.D. are treated was solved long ago by giving them local or personal names such as the Whitechapel Clinic, Lydia Department, or James Pringle House.

Dr. Thin says that only a minority of his patients have legally defined venereal disease but I suspect that most of them would not have come to him if their troubles had not followed extramarital sexual exposure. I am sorry that he hopes to "spend less time coping with emotional problems," as these are just as important to the patient as physical ones. Perhaps it is my seniority, to which Dr. Thin kindly refers, which makes me think, in an old-fashioned way, that being a good doctor is more than being just an interpreter of scientific findings but involves the total care of the patient, mental and physical, most especially, in the management of S.T.D. I think there has been too great a tendency to concentrate on science and research leaving the rest to social workers and nurses. This narrows the specialty and so discourages recruits who are interested in patient care. Dr. Thin and Dr. Harrington Sims (5 July, p. 45) must not think that I wish to lower our standards by adding the ability to do good doctoring to academic qualifications.

The sexually transmitted diseases will remain emotionally charged with an element of guilt attached, which will not be altered by any change in the title of our specialty. That will come when the public itself considers marital sexual intercourse completely acceptable to all parties, which I expect will not be for some time yet.-I am, etc.,

Praed Street Clinic

London $W .2$

JAMES JEFFERISS

\section{Appendicular Carcinoids}

SIR,-Your leading article on the diagnosis of malignant carcinoid syndrome (19 July, p. 122) states: "The commonest site of the tumour is at the tip of the appendix, where the term carcinoid. Pearson and Fitzgerald, however, in reviewing a large series found metastases in $38 \%$ and emphasized that all carcinoids should be considered malignant."

There is a dangerously misleading implication here that appendicular carcinoids frequently metastasize. In fact, Pearson and Fitzgerald wrote, "Metastases were present in $38 \%$ of the present series of nonappendical carcinoid tumours" (my italics). ${ }^{1}$ A more recent publication ${ }^{2}$ states that metastases from appendicular carcinoids are extremely rare (less than $1 \%$ ) and found only in tumours over $2 \mathrm{~cm}$ in diameter.

As carcinoids are the commonest of appendicular tumours (and appendicectomy is the commonest of operations performed by aspiring surgeons) it is important that their benign prognosis should be appreciated.-I am, etc.,

Westminster Hospital,

A. D. MORGAN

London S.W.1

1 Pearson. C. M., and Fitzgerald, P. J., Cancer, 1949, 2. 1005.

2 Morson, B. C., and Dawson, I. M. P. D., Gastrointestinal Patholo

\section{Digoxin Bioavailability: Paradoxical}

\section{Increased Toxicity on Dosage Reduction}

SIR,-Since 1972, when it was first reported ${ }^{1}$ that digoxin tablets B.P. were subject to differences in bioavailability, much work has been published concerning serum levels and clinical response, the formulation factors involved, and the establishment of an in-vitro dissolution test to control this variable. One aspect of the digoxin saga which has not been previously reported is the increased toxicity which can follow dosage reduction. This situation arises because, though there are many brands of the $0 \cdot 25-\mathrm{mg}$ tablet of varying bioavailability marketed in Great Britain, there is only one source, the highly available Lanoxin brand, of $0 \cdot 125-\mathrm{mg}$ and $0.0625-\mathrm{mg}$ tablets. The extent of the problem is shown in the table below, which compares the dissolution results after one hour of the three Lanoxin strengths and the 0.25mg tablets purchased on contract by this hospital. The weight of digoxin in solution at one hour has previously been shown to estimated by the area under the serum concentration/time curve from 0-6 hours. ${ }^{2}$ Dissolution Results of Hospital-contract and Lanoxin
Digoxin Tablets (Mean of Three Experiments with Five Tablets)

\begin{tabular}{|c|c|c|c|}
\hline Tablet & $\begin{array}{c}\text { Mean } \\
\text { Tablet } \\
\text { Content } \\
(\%)\end{array}$ & $\begin{array}{l}\text { Labelled } \\
\text { Strength } \\
\text { in } \\
\text { Solution } \\
\text { at } 1 \mathrm{~h} \\
(\%)\end{array}$ & $\begin{array}{l}\text { Weight } \\
\text { Digoxin in } \\
\text { Solution } \\
\text { at } 1 \mathrm{~h} \\
\text { (mg) }\end{array}$ \\
\hline $\begin{array}{l}\text { Hospital contract } \\
0.25 \mathrm{mg} \\
\text { Lanoxin } 0.25 \mathrm{mg} \\
\text { Lanoxin } 0.125 \mathrm{mg} \\
\text { Lanoxin PG } \\
0.0625 \mathrm{mg}\end{array}$ & $\begin{array}{l}95 \\
97 \\
98 \\
98\end{array}$ & $\begin{array}{l}33 \\
83 \\
87 \\
98\end{array}$ & $\begin{array}{l}0 \cdot 082 \\
0 \cdot 208 \\
0 \cdot 109 \\
0 \cdot 061\end{array}$ \\
\hline
\end{tabular}

It is apparent that a patient receiving the contract $0 \cdot 25-\mathrm{mg}$ tablets and experiencing digoxin toxicity would on reduction of his dosage to the only available $0 \cdot 125-\mathrm{mg}$ tablets find his symptoms exacerbated. Indeed, even by quartering the labelled dosage to the only available $0.0625 \mathrm{mg}$ an effective dosage reduction of only $25 \%$ occurs. As there are correlate $(r=0.995)$ with bioavailability as several brands of digoxin tablets with dissolution profiles similar to the contract brand studied above, the paradoxical increased potency on dosage reduction is capable of widespread occurrence and provides a further reason for the introduction of a dissolution test into the British Pharmacopoia in October this year.-I am, etc.

Queen Elizabeth Hospital,

R. H. LEACH

Birmingham 1 Shaw, T. R. D., and Hamer, J., Lancet, 1972,
$2,303$. E. J., et al., fournal of Pharmacy and
2 Fraser, E. Jourmacology, 1973, 25, 968.
Pharmate

Fees for Family Planning Services

SIR,-Hospital staff are constantly being urged to economize and face up to questions of priority. Actual cuts in the service have already taken place and more are contemplated It is therefore pertinent to question whether the agreement between the profession and the D.H.S.S. on fees for sterilization ( 26 July, p. 260) has been costed, and how this together with the actual cost of providing the facilities will be funded. It is remarkable how the profession has to adopt such unedifying postures when seeking improvements in basic salary, whereas quite generous agreements of this nature can be completed so silently-if it happens to further one of the Government's pet schemes. This no doubt also explains the ability of the same service to issue free contraceptives.

It is also questionable whether, as in the case of the award of shorter working hours and increased statutory holidays to various hospital staff, the D.H.S.S. has realized all the implications, some of which are not directly financial. What priority is to be afforded the clients for "social" sterilization when patients await surgical and gynaecological operations? What will be the attitude of non-medical workers where doctors are being paid for work which is not so much "private" as non-clinical?

All this is quite apart from the more fundamental questions of the state of a nation that pays its doctors to sterilize its people without even the pretence of medical indications. Are doctors still expected to exercise discretion or is it now to be sterilization on demand?-I am, ec.,

D. E. B. Powell

Bridgend General Hospital,

Bridgend, Glamorgan

SIR,-That fees are to be paid for the provision of family planning services through the hospital service (19 July, p. 185 and 26 July, p. 260), particularly sterilization, surely strikes at the root of the idea of patient care. As one who has performed the operation often four times a week in the last 25 years in the interest of the patient, it was a normal part of patient care. Now I realize that it is gilt-edged patient care and all the benefits from management of other aspects of patient care, such as prolapse and even malignant disease, are relegated to a reserve list of little importance so that the desperately short finances of the National Health Service can gild the sterilized gingerbread. How can our negotiation with the D.H.S.S. really justify this item of service payment by which a general practitioner gets more for giving contraceptive advice than for looking after a 